\title{
LICHEN MOSS ASSOCIATION FREQUENTLY FOUND IN MARITIME ANTARCTIC
}

http://dx.doi.org/10.4322/apa.2014.064

\begin{abstract}
Margéli Pereira de Albuquerque ${ }^{1, *}$, Filipe de Carvalho Victoria', Enzo Rebellato¹, Clarissa Keppel Pereira ${ }^{1}$, Cristiane Barbosa D'Oliveira ${ }^{1}$, Jair Putzke ${ }^{2}$, Antonio Batista Pereira ${ }^{1}$
\end{abstract}

\author{
'Universidade Federal do Pampa - UNIPAMPA, Av. Antônio Trilha, 1847, CEP 97300-000, São Gabriel, RS, Brazil \\ 2Universidade de Santa Cruz do Sul - UNISC, Av. Independência, 2298, CEP 96815-900, Santa Cruz do Sul, RS, Brazil \\ *e-mail: margeli_albuquerque@hotmail.com
}

\begin{abstract}
The aim of this work was to report on the lichen-moss association in the ice-free areas of Elephant Island, King George Island, Nelson Island and Deception Island. The study started with the classification and description of the plant communities based primarily on phytosociological and biodiversity data. All data were obtained from 2003-2004 to 2011-2012 austral summers. 12 most frequent lichen-moss association species based on all island records were found. The most frequent association in both studied areas involved foliose-crustose lichen with a moss carpet species, such as Psoroma cinnamomeum Malme with Sanionia uncinata (Hedw.) Loesk. The occurrences for each island as well as the common association found in all sampled islands are demonstrated.
\end{abstract} Keywords: lichen ecology, bryophytes, South Shetlands archipelago, Maritime Antarctic

\section{Introduction}

The composition, abundance and distribution of the plant communities in Antarctica is directly related with the changes in the climatic conditions and the effects of climate warming, resulting in alterations including changes in populations (Frenot et al., 2005; Convey, 2006).

Lichens is the group that has the highest species diversity, meeting the conditions best adapted in Antarctica, having an important contribution in floristic composition in these areas, and their existence is dependent on ice-free regions, climate and a stable substrate (Redon, 1985; Kappen \& Schroeter, 1997). Lewis-Smith (2001) in a phytosociological study found that many species of mosses are associated with dominant species in the formation, reflecting the dependence of these species of mosses because if the dominant species become endangered, the dependent one will become endangered too.

Studies on the coexistence of terrestrial algae species and lichenized fungi were also published, such their relationship within the growth habit and ecological adaptation in the Antarctic environment. Associations are reported between mosses and lichens species, and plant formations growing in associations at King George Islands, Nelson Island and
Elephant Island (Allison \& Lewis-Smith, 1973; Pereira \& Putzke, 1994; Victoria et al., 2006). A mapping of these plant formations is being conducted to infer the environmental changes as well the human impact over the years of the plant composition in the Antarctic ice-free areas.

In order to complement the knowledge of plant communities in the ice-free areas of Maritime Antarctic, associations between lichens and mosses observed during the phytosociological survey made since 2003-2004 up to 2011-2012 austral summers are presented here, as well as the strongest associations found in each surveyed island together with their coverage and frequencies.

\section{Materials and Methods}

Using the phytosociological data obtained since 2003/2004 up to 2011/2012 austral summers all records from lichens found associated to moss species were analyzed. The data was obtained from a survey using Braun-Blanquet phytosociological methods (Braun-Blanquet, 1964), adapted to Antarctic conditions (Kanda, 1986). Whenever possible, samples of lichens with highly developed ascomas (presence 
of apothecia or perithecia) were made. Saxicolous species were pulled out with the help of a geologist hammer, and muscicolous and/or terricolous species, with the help of a knife, to make sure the samples would come out with some substrate. Identification of the species was based on the work of Redon (1985), Ochyra (1998), Pereira \& Putzke (1994) and Putzke \& Pereira (1990). The records were ordered in a frequency range, by the most to the less frequent species found in association.

\section{Results}

Based on the phytosociological data it was possible to verify the occurrence of 12 of the most frequent lichenmoss associations in ice-free areas in Maritime Antarctic (Figure 1). Only three associations were observed in all the sampled islands, being represented by thalose-foliose lichens. The lichen Psoroma cinamomeum Malme was found as being the most frequent lichen found associated with mosses, mainly with species where the cushion is the most frequent life form. Leptogium spp. were also found frequently associated with moss species, but the opposite to that was observed for the previous association, these lichens were found commonly associated with moss carpets such Sanionia uncinata (Hedw.) Loeske.

When comparing the records of all the islands a lower occurrence of fruticose lichens associated with mosses is observed, probably due to this lichen life form being found often in rocky sites where both lichen and moss species are well adapted to colonize rock outcrops directly (Victoria et al., 2006). Cushion mosses occur mainly in rocky terrains in higher places (more than 100mts), often without the need for an early-colonized substrata, growing directly on outcrops (Ochyra, 1998). This moss life form can spread to uncovered lower terrains and then are immediately available for the muscicolous lichen colonization, such as Ochrolechia frigida (Sw.) Lynge. This lichen species was found in several sites in association with Andreaea spp. (Figure 2a) in the sampled islands, except for Deception Island, frequently found in beach plateaus. This association is one of the most frequent in Nelson Island along with Usnea antarctica-Cladonia spp. - Polytrichum juniperinum and Huea coralligera - Sphaeorophorus globosus - Usnea aurantiacoatra - Syntrichia saxicola association (Figure $2 \mathrm{~b}$ and $2 \mathrm{c}$, respectively).

The same association was the most frequently found in Elephant Island (Pereira \& Putzke, 1994; Putzke \& Pereira, 2012). Two associations were found only in a single island, one composed by a fruticose lichen (Usnea spp.Polytrichastrum alpinum) and the other by a dimorphic lichen (Cladonia metacorallifera - Sanionia uncinata, Figure 2d) both in lower frequencies in the King George Island. The association between Psoroma cinnamomeum

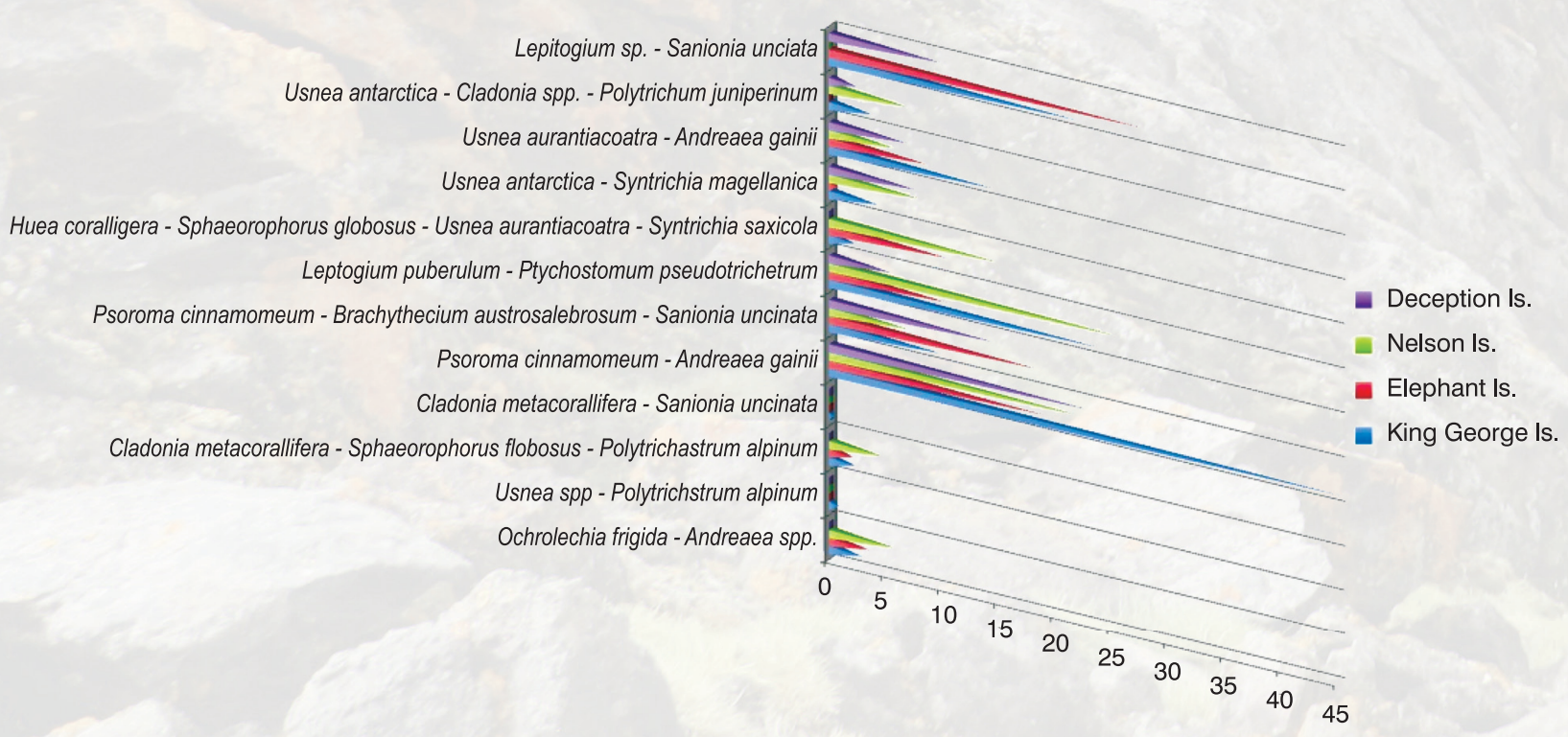

Figure 1. The most lichen-moss associations found in the northern Maritime Antarctic and their frequencies in each island sampled. 

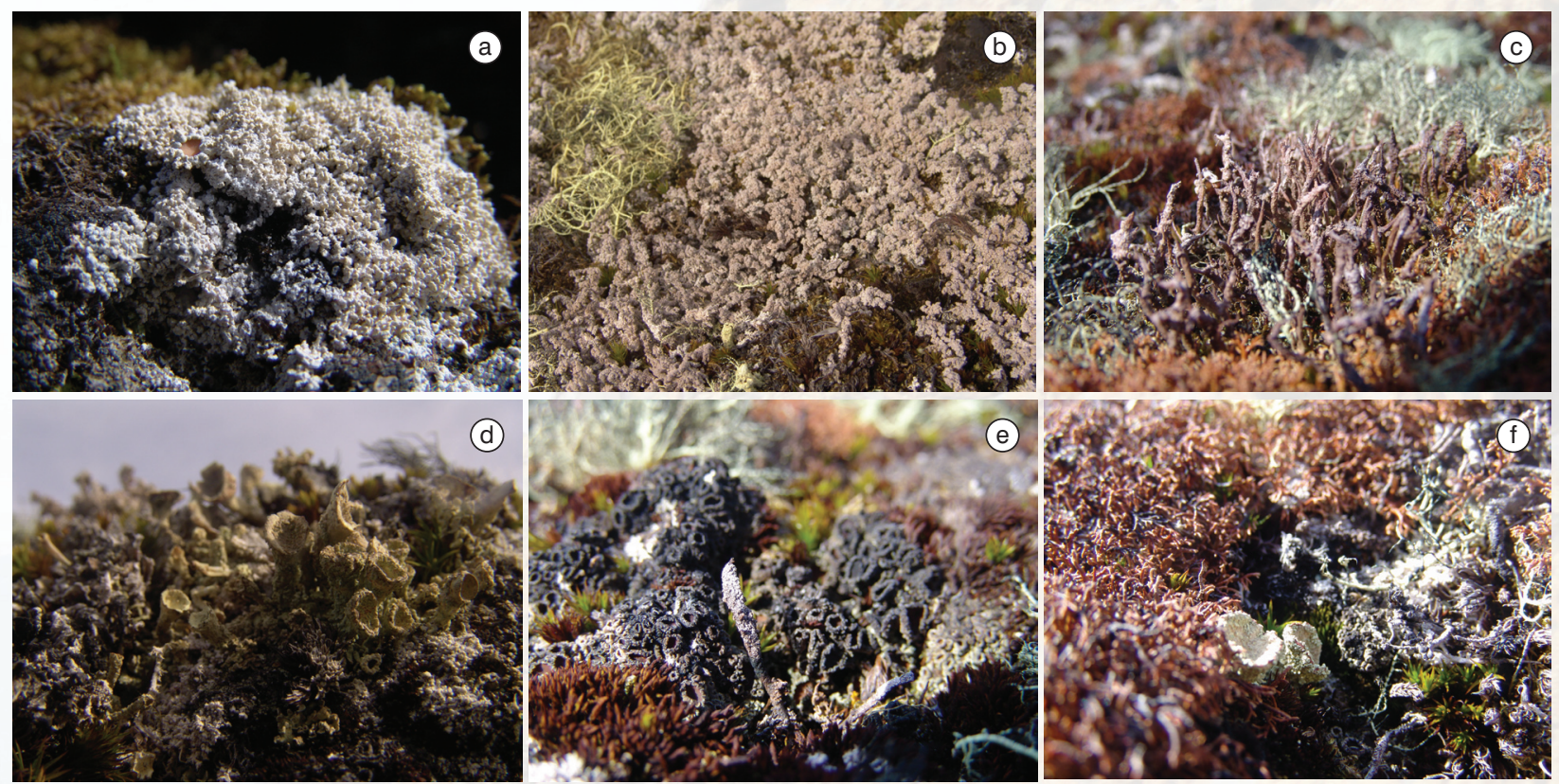

Figure 2. Examples of lichen-moss associations found in the northern Maritime Antarctic. a) Ochrolechia frigida-Andreaea association. b) Usnea antarctica-Cladonia spp.-Polytrichum juniperinum association. c) Huea coralligera-Sphaeorophorus globosus-Usnea aurantiacoatraSyntrichia saxicola association. d) Cladonia metacorallifera-Sanionia uncinata association. e) Psoroma cinnamomeum-Andreaea gainii association. f) Cladonia metacorallifera-Sphaeorophorus globosus-Polytrichastrum alpinum association.

and Andreaea gainii Cardot (Figure 2e) and Leptogium puberulum with Ptychostomum pseudotriquetrum (Hedw.) J.R. Spence \& H.P. Ramsay were the most frequent association observed in the Admiralty Bay area (King George Island). Dimorphic lichen was also found associated with other fruticose lichens, often in higher plateau (Øvstedal \& Lewis-Smith, 2001; Victoria et al., 2009), the latter being found in Elephant, Nelson and King George Islands in the Cladonia metacorallifera-Sphaeorophorus globosus-Polyrtrichastrum alpinum association (Figure 2f).

\section{Discussion}

The plants and lichen species found in Antarctica were developing, mainly, on rocks or moist soils, the rocks being fragmented since the soil had a higher ornithogenic influence. Thus the lichen and moss association were often found in terrain types where both organisms are adapted, corroborating the reports made from several studies on plant communities in Antarctica (Gimingham \& LewisSmith, 1970; Putzke \& Pereira, 1990; Victoria et al., 2006, 2009). Several studies reported lichen and mosses growing at relatively successful growth rates in Polar Regions when compared with other environments (Scott, 1990).

These findings can be related with the human impacts in the area, to decreasing diversity along the two summer seasons (Victoria \& Pereira, 2007). For Sancho et al. (2007) these changes can be a climate change indicator, because that lichen species found in the studied region are susceptible to extreme temperature variation, increasing or decreasing their growth (Sancho et al., 2007), but the fast development and death of the foliose muscicolous lichen cannot be discarded, as certain types of foliose lichens are among the fastest-growing species which have the ability to grow up to one centimeter per year, and this growth rate is unusual in most lichen species (Bednarik, 2004).

\section{Conclusion}

The lichen moss association observed in all plant communities distributed in the South Shetlands Islands can be used as a indicator of plant sucession on the ice-free areas. Further monitoring studies are needed to clarify these diversity changes in plant associations in the Maritime Antarctic. 


\section{Acknowledgements}

This work integrates the National Institute of Science and Technology Antarctic Environmental Research (INCTAPA) that receives scientific and financial support from the National Council for Research and Development (CNPq process: $n^{\circ}$ 574018/2008-5) and Carlos Chagas Research Support Foundation of the State of Rio de
Janeiro (FAPERJ nº E-16/170.023/2008). The authors also acknowledge the support of the Brazilian Ministries of Science, Technology and Innovation (MCTI), of Environment (MMA) and Inter-Ministry Commission for Sea Resources (CIRM). Also the CNPq for the postdoctoral fellowship (CNPq process: 152270/2011-6) to the first author.

\section{References}

Allison, S.E. \& Lewis-Smith, R.I. (1973). The vegetation of Elephant Island, South Shetland Island. British Antarctic Survey Bulletin, 33-34:185-212

Bednarik, R.G. (2004). Lichenometry. Available from: < http://mc2.vicnet.net.au/> (accessed: 4 Nov. 2004)

Braun-Blanquet, J. (1964). Pflanzensociologie. 3. Aufl. Wien, Springer. 865 p.

Convey, P. (2006). Antarctic climate change and its inXuences on terrestrial ecosystems. In: Bergstrom, D.M.; Convey, P.; Huiskes, A.H.L. (Eds). Trends in Antarctic terrestrial and limnetic ecosystems: Antarctica as a global indicator. Dordrecht: Springer. p. 253-272.

Frenot, Y.; Chown, S.L.; Whinam, J.; Selkirk, P.; Convey, P.; Skotnicki, M. \& Bergstrom, D. (2005). Biological invasions in the Antarctic: extent, impacts and implications. Biological Reviews,80:45-72.

Gimingham, C.H. \& Lewis-Smith, R.I. (1970). Bryophyte and lichen communities in the maritime Antarctic. In: Holdgate, R. Antarctic Ecology. London: Acad Press. p. 752-785.

Kappen, L. \& Schroeter, B. (1997). Activity of lichens under the influence of snow and ice. Proceedings of the NIPR Symposium on Polar Biology, 10: 163-168.

Lewis-Smith, R.I. (2001). Plant colonization response to climate changes in the Antarctica. Folia. Facultatis Scientiarium Naturalium Universitatis Masarykianae Brunensis, Geográfica, 25: 19-33.

Ochyra, R. (1998). The moss flora of King George Island Antarctica. Cracow: Polish Academy of Sciences. 279 p.

Øvstedal, D.O. \& Lewis-Smith, R.I. (2001). Lichens of Antarctica and South Georgia - A guide to their identification and ecology. Studies in Polar Research, Cambridge University Press. 411 p.

Pereira, A.B. \& Putzke, J. (1994). Floristic composition of Stinker Point. Elephant Island, Antarctica. Korian Journal of Polar Research, 5(2): 37-47

Putzke, J. \& Pereira, A.B. (1990). Mosses of King George Island, Antarctica. Pesquisa Antártica Brasileira, 2(1): 17-71.

Putzke, J. \& Pereira, A.B. (2012). Fungos Muscícolas Na llha Elefante - Antártica. Caderno de Pesquisa, Série Biologia, 24(1): 1-4.

Redon, J. (1985). Liquens Antarticos. Santiago de Chile: Instituto Antártico Chileno (INACH). 123 p.

Sancho, L.G.; Green, T.G.A. \& Pintado, A. (2007). Slowest to fastest: Extreme range in lichen growth rates supports their use as an indicator of climate change in Antarctica. Flora - Morphology, Distribution, Functional Ecology of Plants, 202(8): 667-673.

Scott, J.J. (1990). Changes in vegetation on Heard Island 1947-1987. In: Kerry, K.R. \& Hempel, G. (Eds.). Antarctic ecosystems. Ecological change and conservation. Berlin, Germany: Springer. p. 61-76.

Victoria, F.C.; Albuquerque, M.P. \& Pereira, A.B. (2006). Lichen-Moss associations in plant communities of the Southwest Admiralty Bay, King George Island, Antarctica. Neotropical Biology and Conservation. 1(2): 84-89.

Victoria, F.C. \& Pereira, A.B. (2007). Índice de valor ecológico (IES) como ferramentas para estudos fitossociológicos e conservação das espécies de musgos da Baia do Almirantado, Ilha Rei George, Antártica Marítima. Oecologia Brasiliensis, 11: $50-55$

Victoria, F.C.; Costa, D.P. \& Pereira, A.B. (2009). Life-forms of moss species in defrosting areas of king George island, South Shethland islands, Antarctica. Bioscience Journal, 25(3): 151-160. 